\title{
Study on the Abuse of Control Right by the Controlling Shareholders of State-Owned Enterprises in China
}

\author{
Xiaoyan Wang \\ School of Economics \& Management, Northwest University, Xi’an, Shaanxi, China
}

Keywords: Controlling shareholder; Abuse of control right; Corporate governance

\begin{abstract}
In China's rapidly developing capital market, the problem of controlling shareholders abusing their control rights has not been solved. On the basis of analyzing the performance of the controlling shareholder's abuse of power, this paper analyzes the harmful consequences of such abuse of power, and puts forward some countermeasures and Suggestions to solve the problem of the controlling shareholder's abuse of control power, so as to provide a basis for improving the corporate governance system in China.
\end{abstract}

Since the reform of state-owned enterprises in China, a large number of state-owned enterprises have been transformed into joint-stock companies. At present, many listed companies and group companies in China are derived from the reorganization of state-owned enterprises. The state, as the controlling shareholder, holds the majority of the shares of the company after the restructuring, thus forming the widespread phenomenon of "one dominant share". After the completion of the restructuring of state-owned enterprises, however, the reduction of state-owned shares is relatively lagging behind, and the non-tradable nature of state-owned shares has formed a unique phenomenon of non-tradable shares. As the controlling shareholder of the state, the circulation of the shares held by the state is limited, which leads to the stable status of the controlling shareholders to a certain extent. At present, China's stake in the company structure, the principle of capital majority of alienation and the corporate governance structure is scientific problems should produce the abuse of corporate controlling shareholder control, because of the complexity of the company and the interests of the parties subject direction often appear contradictions and even conflicts, which led to the interests of the game between the main body. In corporate governance if you don't have a set of scientific and effective governance mechanism governing the exercise of the controlling shareholder control, then company and the interests of minority shareholders and creditors must be difficult to secure. How to properly solve the controlling shareholder control exercise and regulation of the relevant legal issues, science to establish regulation controlling shareholders improper exercise control of the standard system, directly related to the future development direction of corporate governance system in China. Therefore, it is still an important issue that we should continue to study deeply to regulate the exercise of controlling shareholder's control right and more reasonably protect the rights and interests of minority shareholders and their creditors.

\section{Performance of Controlling Shareholders' Abuses of Power}

The controlling shareholder abuses the corporate personality. In the financial aspect, when the company's property and the shareholder's property cannot draw a clear line or make a clear distinction, the shareholder can occupy or misappropriate the company's property at will, thus greatly reducing or even losing the solvency of the company and endangering the interests of the whole company. In terms of business, the two companies controlled by the controlling shareholders overlap or cover each other in the business scope, which makes the counterpart unable to distinguish the transaction object or the subject of the transaction behavior and the transaction result unclear, so that the interests of the counterpart cannot be guaranteed. In terms of personnel, shareholders hold important positions in their own companies or share a set of personnel system with two companies, which greatly affects the supervision function and decision-making ability of the internal organization of the company, thus losing the independence of the company's 
personality.

Abuse of control rights damages the interests of minority shareholders. Due to the huge disparity between the controlling shareholder's dominant position and the strength of both sides, the controlling shareholder with the majority of shares wins easily in the tug of war for the decision-making right, while the minority shareholder with less shares can only obey. When the controlling shareholder gains control through the equity advantage, driven by interests, it will more recklessly exclude the influence of minority shareholders on the company's decision, so as to realize its own interests and ignore the interests of others. On the issue of profit distribution, the controlling shareholders usually specify the dividend accounting and distribution system that is beneficial to them, so as to make the company profit flow to the controlling shareholders. Some companies also through the way of continuous accumulation fund to achieve the purpose of not distributing dividends to small and medium-sized shareholders, so that the investment of small and medium-sized shareholders can not get a reasonable return [1]. Many companies clearly have the ability to distribute dividends, but they are not willing to distribute dividends and share profits to minority shareholders, or pay annual salary or bonus to their senior managers in other ways, which directly results in the infringement of the reasonable earnings of minority shareholders.

Abuse of control right to encroach on company property. Controlling shareholders improperly use their control position in the company to directly or indirectly influence or even dominate the company's operating decisions and achieve the purpose of interest transmission by selling at a high price or buying at a low price. This kind of transaction, real estate mortgage, agency or other transfer of property between the company and the controlling shareholder or the controlling shareholder's affiliate that is beneficial to the controlling shareholder is bound to cause damage to the company's interests. Financing in the process of small and medium-sized shareholders in the company mostly direct investment took the form of cash, and the controlling shareholders usually non-cash capital contribution methods such as such as physical, resulting in asset assessment when there is a big space, can be low value asset price assessment, then subscribe for more shares to encroach on the purpose of company assets, in the interests of minority shareholders is changed to the occupation.

\section{The Harmful Consequences of the Controlling Shareholder's Abuse of Power}

Infringement on the interests of the company and minority shareholders. The controlling shareholder's unfair related party transaction and transfer of the company's property seriously damage the interests of the company. Controlling shareholders will often make good on the claim, in violation of laws and regulations and the company's articles of association will be the company as the guarantor of their loans, so the company will be jointly and severally liable for their debts with the controlling shareholders, when the controlling shareholders are unable to repay the debt, the company will assume the liability for repayment. In this way, the abuse of control by controlling shareholders will not only damage the interests of the company, but also may make the company into a huge risk. Controlling shareholders tend to in order to obtain the maximization of its interests while ignoring the interests of minority shareholders, the small and medium-sized shareholders lost voice, which only has the right to vote, in the form of the substance being shut out of the right to vote, could not really involved in the decision-making of the company's operating and suffer on interests, strict operation of the small and medium-sized shareholders investment enthusiasm, also violated their expectation interests of their investments have.

Damage to the rights and interests of the company's creditors. For the creditors who have creditor's right and debt relationship with the company, they can't know the operation and management status of the company in time, and they can only conduct supervision through limited ways. Controlling shareholders abuse the company legal person independent personality, with individual and the company's main body qualifications, when unable to bear the liability to use correlation property of the transfer or use of the limited liability of shareholders to escape debts, the creditor sued the company, the company has become a shell company, unable to repay debts, the creditors unable to exercise the creditor's rights and cause serious damage to the creditor rights and 
interests [2].

Disturbance to the security market order. Controlling shareholder holds the majority of decision-making power, so the controlling shareholders often dominate or control the board of directors, board of supervisors and senior managers in the company, for the company's internal information, controlling shareholders usually because of their advantage position update, more comprehensive information and that in itself is not in the aspect of information knowledge, etc. With "company is also responsible for the timely information disclosure obligations, if using the \# the dominance of controlling shareholders not to disclose or make malicious disclosure, but stock market investors are often through the company's disclosure of information to understand the company's specific capital and operating conditions, false, false or partial information disclosure would have serious misleading to them, make them in the state of being blind to make investment decisions, take the initiative to let yourself into a huge risk. In the long run, if investors fail to evaluate the company with real standards, they will lose their trust in the securities market, causing chaos and deterioration of the securities market and failing to develop healthily and orderly.

\section{Countermeasures to Prevent Abuse of Control Right}

Increase the proportion of independent directors and strengthen their functions, and appropriately reduce the proportion of executive directors. Based on the weak function of independent directors in China, the proportion of independent directors can be appropriately increased, which not only strengthens their supervision function, but also plays a role in strengthening the control of the company. In addition, it is necessary to clarify and strengthen several requirements on the exercise of functions and powers of the independent director. The second is to strengthen the review of the legality and compliance of company resolutions; finally, the company's articles of association and whether the system will cause harm to the interests of the company and shareholders. The corporate governance structure of li is to check and balance, if the management can directly manipulate the board of directors, then the interests of minority shareholders may suffer losses due to the agency cost. Therefore, the number of management personnel in the board of directors should be appropriately reduced. The management and the board of directors play different roles in the corporate governance structure. The board of directors exercises the function of decision-making, while the management mainly exercises the management function of specific affairs of the company.

Improve the supervisor system to enhance the independence of supervisors. Firstly, it starts with the election system of the board of supervisors. For the nomination of the first member of the board of supervisors shall establish an effective mechanism, examine whether the with the company's controlling shareholder or the largest shareholder has a direct or indirect interest relations as well as other normal driving the functions and powers of other relations may affect supervisors, second to strictly enforce the rules of the company board of supervisors shall have workers' representatives. Independent supervisor system can be introduced in China to strengthen the independence and supervision of the board of supervisors. Independent supervisors' interests are independent from those of the company, which can not only get rid of the improper intervention and control of the controlling shareholders or the company operators to a certain extent, but also guarantee their independence within the company. In addition, as for the functions and powers of independent supervisors, they should first be required to cooperate with the independent directors and clarify the scope of their rights. It should be clear that their functions and powers are also within the board of directors and the board of supervisors respectively. Secondly, the right to know of the independent supervisor should be guaranteed, and it should be made clear that the independent supervisor has the right to consult the company's financial documents and accounts, and has the right to question the company's directors or senior executives.

Make clear the identification standards of corporate personality confusion. Not all mixed behaviors can be applied to the denial system of corporate personality. In the case of identification of mixed personality, it is necessary to consider whether it has reached the degree of serious infringement and damage of corporate personality or will independence. For example, in the 
judgment of financial mixed at the same time, through the survey between controlling shareholders and the company or a holding company with subsidiaries is done between accounts and money make a clear distinction between, whether fixed assets used independently, and so on and so forth to maintain, but also pay attention to the company's independent property rights whether loss, if the company still has the independence of the ownership of the property rights form, will not be regarded as financial confusion; In the judgment of business mixing, it mainly investigates whether the business nature and scope between the controlling shareholder and the company are the same. At this time, it is necessary to pay attention to whether the business mixing is only similar or completely mixed. If the degree of similarity between the two businesses has made it impossible for the counterpart to distinguish, it should be considered as business mixing. In terms of the personnel confusion, we can not identify the personnel confusion only by the cross-officing of personnel, and the specific situation still has to rise to the level of whether to damage the independence of the company's personality.

Establish a stricter civil liability system for controlling shareholders, and clarify the relief methods and channels of creditors to ensure the realization of creditors' rights. The duty of good faith of the controlling shareholder is a basic principle to prevent its abuse of control right from damaging the rights and interests of other small and medium shareholders. Therefore, the principle of good faith obligation should be applied to the protection of creditors in the form of statutory law, and the civil liability system of controlling shareholders should be established on the basis of good faith obligation.

Improve the voting exclusion system, the share repurchase system for dissenting shareholders, the shareholder direct litigation system, and the shareholder representative litigation system. Suggest to involve the interests of minority shareholders resolution shall stipulate only by small and medium-sized shareholders, at the same time of related transactions will be the controlling shareholder voting rights ruled out up to level specified in the company law, company law has not only limited to the listed company, expand the scope of application, strengthen the regulation system of the force of law, through to strengthen the system of getting rid of vote in order to achieve better effect of regulating the controlling shareholder rights. In the aspect of the share repurchase system, the right to request for share repurchase of dissenting shareholders should be improved, including the scope of applicable subjects, applicable conditions, repurchase procedures and relevant legal liabilities. The principle of good faith obligation in China is integrated into the system, which stipulates that minority shareholders can bring direct lawsuits when the controlling shareholders violate the obligation of good faith and infringe their legitimate rights and interests, and makes clear that the controlling shareholders have the right to bring lawsuits when they violate the obligation of good faith and arbitrarily infringe the legal or agreed legal rights and interests of minority shareholders. In the legislation, the qualifications of the plaintiff shareholders who file the shareholder representative action should be appropriately relaxed, the dual restrictions of shareholding ratio and shareholding time should be abolished, and the "shareholding rule" should be used uniformly.

\section{References}

[1] Thompson, Robert B. The Shareholder's Cause of Action for Oppression. The Business Lawyer, 1993: 699-745.

[2] Siegel, Mary. Fiduciary Duty Myths in Close Corporate Law. Del. j. Corp. L., 2004, 29: 377. 